\title{
PERLINDUNGAN HUKUM TERHADAP HAK-HAK KARYAWAN TETAP \\ DALAM HAL TERJADI PEMUTUSAN HUBUNGAN KERJA (PHK) \\ MENURUT UNDANG-UNDANG NOMOR 13 TAHUN 2003
}

\author{
Oleh : \\ I Nyoman Suandika, SH, MH \\ Program Studi Fakultas Hukum Universitas Mahendradatta \\ Jl. Ken Arok No. 12, Peguyangan Denpasar Utara, Bali 80115 \\ (pakden278@gmail.com)
}

\begin{abstract}
Abstrak.
Dalam suatu hubungan kerja seperti halnya hubungan hukum lainnya tidak selalu berjalan dengan lancar, karena keinginan salah satu pihak (umumnya pekerja) tidak selalu dapat dipenuhi oleh pihak lainnya (pengusaha), sehingga ini akan menimbulkan masalah dalam hubungan kerja seperti misalnya pemutusan hubungan kerja (PHK). rumusan masalah dalam penelitian ini adalah : 1. Faktor-faktor apakah yang menyebabkan terjadinya peutusan hubungan kerja (PHK) terhadap karyawan tetap. 2. Bagaimanakah akibat hukum apabila terjadi pemutusan hubungan kerja (PHK) terhadap karyawan tetap menurut Undang-undang Nomor 13 Tahun 2003. Penelitian ini menggunakan tipe penelitian normatif yaitu penelitian dengan cara meneliti bahan pustaka atau data skunder. Faktor yang menyebabkan pengusaha melakukan PHK terhadap pekerja/buruh menurut Undang-Undang Nomor 13 tahun 2003 adalah : a) pelanggaran perjanjian kerja, peraturan perusahaan, dan perjanjian kerja bersama. b) Pelanggaran atau kesalahan berat. c) Pekerja ditahan pihak berwajib. d) Karena perubahan status perusahaan. e) karena perusahaan tutup. e) Karena pekerja terjerat kasus pidana. f) Karena perusahaan tutup. g) perusahaan pailit. h) Pekerja mangkir dari pekerjaannya. Akibat hukum terjadinya pemutusan hubungan kerja terhadap pekerja/buruh menurut UU No.13/2003 dalam Pasal 156 ayat (1) adalah menimbulkan kewajiban kepada pengusaha untuk memberikan ; a) Uang pesangon, b. Uang penghargaan masa kerja (uang jasa). C. Uang pergantian hak. D. Uang pisah.
\end{abstract}

Kata Kunci : Pemutusan Hubungan Kerja, akibat hukum.

\begin{abstract}
,
In a work relationship such as other legal relationships it does not always run smoothly, because the wishes of one party (generally workers) cannot always be fulfilled by other parties (employers), so that this will cause problems in work relationships such as termination of employment (layoffs) ) the formulation of the problem in this study are: 1. What factors cause the termination of employment (FLE) to permanent employees. 2. What is the legal effect if there is a termination of employment (FLE) against permanent employees according to Law Number 13 of 2003. This study uses a type of normative research, namely research by examining library material or secondary data. Factors that caused employers to lay off workers / laborers according to Law No. 13 of 2003 are: a) violations of work agreements, company regulations, and collective labor agreements. $b$ )
\end{abstract}


Violations or serious mistakes. c) Employees are detained by the authorities. d) Due to changes in company status. e) because the company is closed. e) Because workers are caught in a criminal case. f) Because the company is closed. g) bankrupt company. h) Workers are absent from their jobs. The legal consequences of termination of employment with workers / laborers according to Law No.13 / 2003 in Article 156 paragraph (1) are to give obligations to employers to provide; a) Severance pay, $b$. Working period award money (service fees). C. Reimbursement of rights. D. Separate money.

Keywords: Termination of employment, legal consequences.

\section{PENDAHULUAN}

Dalam suatu hubungan kerja seperti halnya hubungan hukum lainnya tidak selalu berjalan dengan lancar, karena keinginan salah satu pihak (umumnya pekerja) tidak selalu dapat dipenuhi oleh pihak lainnya (pengusaha), sehingga ini akan menimbulkan masalah dalam hubungan kerja seperti misalnya pemutusan hubungan kerja (PHK). PHK merupakan permasalahan yang sangat kompleks karena mempunyai kaitan dengan pengangguran, kriminalitas, dan kesempatan kerja karena laju perkembangan industri usaha serta meningkatnya jumblah angkatan kerja. PHK merupakan awal kesengsaraan bagi pekerja/buruh karena sejak saat itu penderitaan akan menimpa dirinya dengan hilangnya penghasilan yang diterima selama bekerja.Pemerintah dalam hal ini telah mengeluarkan peraturan-peraturan yang berkaitan dengan PHK karena pemerintah memiliki kewajiban untuk menjaga pertumbuhan ekonomi sembari menjamin warganegaranya untuk menciptakan masyarakat yang adil, makmur, dan sejahtera yang peraturannya secara terus menerus disempurnakan, namum PHK masih juga terjadi dimana-mana.

\section{RUMUSAN MASALAH}

Berdasarkan latarbelakang diatas maka rumusan masalah yang diangkat dalam penulisan ini adalah :

1. Faktor-faktor apakah yang menyebabkan terjadinya peutusan hubungan kerja (PHK) terhadap karyawan tetap.

2. Bagaimanakah akibat hukum apabila terjadi pemutusan hubungan kerja (PHK) terhadap karyawan tetap menurut Undang-undang Nomor 13 Tahun 2003.

\section{METODE PENELITIAN}

Penelitian ini menggunakan tipe penelitian normatif yaitu penelitian dengan cara meneliti bahan pustaka atau 
data skunder. Sumber bahan hukum yang digunakan adalah a) sumber bahan hukum primer yaitu bahan hukum yang bersifat autoritatif artinya mempunyai otoritas yang terdiri dari peraturan perundang-undangan, catatan-catatan resmi atau risalah-risalah.b) sumber bahan hukum skunder yaitu semua bahan hukum yang diperolh dari semua publikasi tentang bahan hukum yang bukan merupajan dokumen-dokumen resmi, publikasi ini meliputi bahanbahan pustaka dan literatur-literatur yang ada hubungannya dengan masalah yang dibahas

\section{PEMBAHASAN}

\subsection{Pemutusan Hubungan Kerja Terhadap Karyawan Tetap}

Berdasarkan

ketentuan

Kep.100/Men/VI/2004 Pasal 1 angka 2 perjanjian kerja waktu tidak tertentu (PKWTT) atau pekerjanya disebut karyawan tetap adalah perjanjian kerja antara pekerja/buruh dengan pengusaha untuk mengadakan hubungan kerja yang bersifat tetap. Dan berdasarkan ketentuan Pasal 1 angka 25 UU No. 13/2003 bahwa pemutusan hubungan kerja adalah pengakhiran hubungan kerja karena suatu hal tertentu yang mengakibatkan berakhirnya hak dan kewajiban antara pekerja/buruh dan pengusaha. Menurut Hani Subagyo pemutusan hubungan kerja ada 4 macam yaitu : a) Pemutusan hubungan kerja oleh pekerja/buruh. b) pemutusan hubungan kerja demi hukum. c) Pemutusan hubungan kerja oleh pengadilan. d) Pemutusan hubungan kerja oleh pengusaha.

Faktor yang menyebabkan pengusaha melakukan PHK terhadap pekerja/buruh menurut Undang-Undang Nomor 13 tahun 2003 adalah : a) pelanggaran perjanjian kerja, peraturan perusahaan, dan perjanjian kerja bersama. b) Pelanggaran atau kesalahan berat. c) Pekerja ditahan pihak berwajib. d) Karena perubahan status perusahaan. e) karena perusahaan tutup. e) Karena pekerja terjerat kasus pidana. f) Karena perusahaan tutup. g) perusahaan pailit. h) Pekerja mangkir dari pekerjaannya. Adapun larangan bagi pengusaha melakukan pemutusan hubungan kerja terhadap pekerja/buruh menurut UU No. 13 Tahun 2003 dalam Pasal 153 adalah : a) Pekerja berhalangan masuk kerja karena sakit menurut keterangan dokter selama waktu tidak melampaui 12 bulan secara terus-menerus. b) Pekerja berhalangan menjalankan pekerjaannya karena memenuhi kewajiban terhadap negara sesuai dengan peraturan 
perundag-undangan yang berlaku. c) Pekerja menjalankan ibadah yang di perintahkan agamanya. d) Pekerja menikah. e) Pekerja perempuan hamil. f) Pekerja mempunyai pertalian darah dan atau ikatan perkawinan dengan pekerja lainnya didalam suatu perusahaan kecuali telah di atur dalam peraaturan perusahaan, atau perjanjian kerja bersama. g) Pekerja mendirikan, menjadi anggota dan atau pengurus serikat pekerja,pekerja melakukan kegiatan serikat pekerja di luar jam kerja, atau di dalam jam kerja atas kesepakatan pengusaha atau berdasarkan ketentuan yang di atur dalam perjanjian kerja, peraturan perusahaan, atau perjanjian kerja bersama. h) Pekerja yang mengadukan pengusaha kepada yang berwajib mengenmai perbuatan pengusaha yang melakukan tindak pidana kejahatan. i) Karena perbedaan paham, agama, aliran politik, suku, warna kulit, golongan, jenis kelamin, kondisi fisik, atau status perkawinan. j) Pekerja dalam keadaan cacat tetap,sakit akibat kecelakaan kerja,atau sakit karena hubungan kerja yang menurut keterangan dokter yang jangka waktu penyembuhannya belum dapat dipastikan. Prosedur PHK menurut Keputusan Menteri Tenaga Kerja dan
Transmigrasi RI Nomor Kep 78/Men/2001 dalam pasal (6) adalah 1) sebelum mendapatkan izin dari Panitia Daerah atau Panitia Pusat pengusaha dapat melakukan skorsing sesuai dengan perjanjian kerja, peraturan perusahaan, atau perjanjian kerja bersama. 2) Dalam hal melakukan skorsing pengusaha wajib membayar upah selama skorsing paling sedikit sebesar $75 \%$ dari upah yang diterima pekerja. 3) Harus dilakukan secara tertulis dan disampaikan kepada ekerja dengan alasan yang jelas dan kepada pekerja yang bersangkutan harus diberikan kesempatan untuk membela diri. 4) Upah selama skorsing diberikan paling lama 6 bulan. 5) Setelah masa skorsing selesai pengusaha berkewajiban tidak membayar upah kecuali ditentukan lain oleh Panitia daerah atau Panitia Pusat. Selama izin PHK belum diberika oleh Panitia Pusat atau Panitia daerah dan pengusaha tidak melakukan skorsing maka pengusaha membayar upah $100 \%$ selama proses, dan dalam hal terjadi PHK yang disebabkan karena pengusaha tidak mengajukan permohonan izin maka PHK tersebut menjadi perselisihan serta sebelum ada putusan dari Panitia Daerah atau Panitia Pusat upah pekerja selama proses dibayar $100 \%$. 
4.2 Akibat Hukum Apabila Terjadi Pemutusan Hubungan Kerja Terhadap Karyawan Tetap Menurut UU No. 13 Tahun 2003

Mengingat kedudukan pekerja yang lebih rendah dibandingkan dengan majikan maka perlu adanya campur tangan dari pemerintah untuk memberikan perlindungan hukumnya. Perlindungan secara etimologis diartikan sebagai tempat berlindung, perbuatan melindungi. Unsur-unsur terhadap makna perlindungan itu sendiri adalah ada jaminan terhadap pelaksanaan serangkaian hak dan terhindar dari diskriminasi serta ada jaminan akan rasa aman dari gangguan pihak lain. Menurut Imam Soepomo perlindungan hukum bagi pekerja meliputi lima bidang yaitu : 1) Bidang pengerahan/Penempatan tenaga kerja. 2) Bidang hubungan kerja. 3) Bidang kesehatan kerja. 4) Bidang keamanan kerja. 5) Bidang jaminan sosial.

Akibat hukum terjadinya pemutusan hubungan kerja terhadap pekerja/buruh menurut UU No.13/2003 dalam Pasal 156 ayat (1) adalah menimbulkan kewajiban kepada pengusaha untuk memberikan :

a. Uang pesangon merupakan pembayaran dalam bentuk uang dari pengusaha kepada pekerja sebagai akibat adanya pemutusan hubungan kerja yang bersangkutan. Penghitungan uang pesangon menurut UU No. 13/2003 dalam pasal 156 ayat (2) adalah : 1) Masa kerja kurang dari setahun sebesar satu bulan upah.Masa kerja satu tahun atau lebih, tetapi kurang dari dua tahun, sebesar dua bulan upah. 2)Masa kerja dua tahun atau lebih tetapi kurang dari tiga tahun, sebesar tiga bulan upah. 3)Masa kerja tiga tahun atau lebih tetapi kurang dari empat tahun, sebesar empat bulan upah. 4)Masa kerja empat tahun atau lebih tetapi kurang dari lima tahun, sebesar lima bulan upah. 5) Masa kerja lima tahun atau lebh tetapi kurang dari enam tahun, sebesar enam bulan upah. 6) Masa kerja enam tahun atau lebih tetapi kurang dari tujuh tahun, sebesar tujuh bulan upah. 7) Masa kerja tujuh tahun atau lebih tetapi kurang dari delapan tahun, sebesar delapan bulan upah. 8) Masa kerja delapan tahun atau lebih, sebesar sembilan bulan upah.

b. Uang penghargaan masa kerja (uang jasa) adalah uang jasa yang dibayarkan oleh pengusaha kepada pekerja yang jumlahnya dikaitkan 
dengan lamanya masa kerja. dasar penghitungannya menurut UU No. 13/2003 dalam Pasal 156 ayat (3) adalah :1) Masa kerja tiga tahun atau lebih tetapi kurang dari enam tahun, sebesar dua bulan upah. 2) Masa kerja enam tahun atau lebih tetapi kurang dari sembilan tahun, sebesar tiga bulan upah. 3) Masa kerja sembilan tahun atau lebih tetapi kuramng dari 12 tahun, sebesar empat bulan upah. 4) Masa kerja 12 tahun atau lebih tetapi kurang dari 15 tahun, sebesar lima bulan upah. 5) Masa kerja 15 tahun atau lebih tetapi kurang dari 18 tahun, sebesar enam bulan upah. 6) Masa kerja 18 tahun atau lebih tetapi kurang dari 21 tahun, sebesar tujuh bulan upah. 7) Masa kerja 21 tahun atau lebih tetapi kurang dari 24 tahun, sebesar delapan bulan upah. 8) Masa kerja 24 tahun atau lebih, sebesar sepuluh bulan upah.

c. Uang pergantian hak menurut UU No. 13/2003 dalam pasal 156 ayat (4) meliputi : 1) Cuti tahunan yang belum diambil maupun yang belum gugur.

2) Ongkos pulang pekerja serta keluarganya untuk kembali ke daerah asalnya, biaya ganti perumahan, perawatan, dan obat-obatan yang besarnya $15 \%$ dari uang pesangon dan atau uang penghargaan sesuai dengan masa kerjanya. 3) Hak lainnya yang diatur dalam perjanjian kerja, perjanjian kerja bersama dan peraturan perusahaan.

d. Uang pisah adalah pemberian berupa uang dari pengusaha kepada pekerja atas pengunduran diri secara baikbaik dan sesuai dengan prosedur dan ketentuan yang diajukan secara terulis 30 hari sebelum tanggal pengunduran diri.

\section{SIMPULAN DAN SARAN}

Berdasarkan uraian dan penjelasan dalam pembahasan di atas maka dapat ditarik beberapa simpulan yaitu :

1. Pemutusan hubungan kerja menurut UU No.13/2003 dalam pasal 1 angka 25 adalah pengakhiran hubungan kerja antara pengusaha dengan pekerja karena suatu hal tertentu yang mengakibatkan berakhirnya hak dan kewajiban antara pekerja dan pengusaha. Faktor-faktor penyebab terjadinya pemutusan hubungan kerja oleh pengusaha kepada pekerja menurut UU No. 13/2003 adalah : a) pelanggaran perjanjian kerja, peraturan perusahaan atau perjanjian kerja bersama. b) Pelanggaran atau kesalahan berat. c) Pekerja ditahan 
pihak berwajib. d) Pekerja terjerat kasus pidana. e) Karena perubahan status perusahaan. f) Karena perusahaan tutup. g) Perusahaan pailit. h) Pekerja atau buruh mangkir dari pekerjaannya.

2. Akibat hukum terjadinya pemutusan hubungan kerja oleh pengusaha kepada pekerja menurut UU No. 13/2003 dalam pasal 156 ayat (1) adalah menimbulkan kewajiban kepada pengusaha untuk membayar uang pesangon, uang penghargaan masa kerja (uang jasa), uang pergantian hak, dan uang pisah kepada pekerja yang mengalami pemutusan hubungan kerja. a) Uang pesangon merupakan pembayaran dalam bentuk uang dari pengusaha kepada pekerja sebagai akibat adanya pemutusan hubungan kerja yang bersangkutan. b) Uang penghargaan masa kerja (uang jasa) adalah uang jasa yang dibayarkan oleh pengusaha kepada pekerja yang jumlahnya dikaitkan dengan lamanya masa kerja. c) Uang pergantian hak menurut UU No. 13/2003 dalam pasal 156 ayat (4) meliputi : 1) Cuti tahunan yang belum diambil maupun yang belum gugur. 2) Ongkos pulang pekerja serta keluarganya untuk kembali ke daerah asalnya, biaya ganti perumahan, perawatan, dan obat-obatan yang besarnya $15 \%$ dari uang pesangon dan atau uang penghargaan sesuai dengan masa kerjanya. 3) Hak lainnya yang diatur dalam perjanjian kerja, perjanjian kerja bersama dan peraturan perusahaan. d) Uang pisah adalah pemberian berupa uang dari pengusaha kepada pekerja atas pengunduran diri secara baik-baik dan sesuai dengan prosedur dan ketentuan yang diajukan secara terulis 30 hari sebelum tanggal pengunduran diri. Perhitungan pesangon masih dapat berubah, seperti yang disebutkan pada Pasal 156 ayat (5) UU No. 13 tahun 2003, bahwa besarnya uang pesangon dapat mengalami perubahan sebagai penyesuaian ini terjadi karena adanya berbagai alasan seperti bila pekerja melakukan pelanggaran berat, misalnya melakukan tindak pidana, melanggar peraturan kerja, merugikan perusahaan, mengancam keberlangsungan perusahaan, perubahan internal perusahaan misalnya perusahaan mengalami kebangkrutan, perusahaan mengalami merger, atau perusahaan mengalami perubahan kepemilikan. Berdasarkan 
pembahasan yang diuraikan di atas mengenai PHK. Maka penulis melalui tulisan ini menyampaikan saran kepada pihak pengusaha dan pekerja karena pemutusan hubungan kerja merupakan hal yang sangat merugikan bagi kedua belah pihak maka kedua belah pihak (pengusaha dan pekerja) harus saling menjaga hubungan kerja dalam menjalankan perusahaan, sehingga dengan berjalannya perusahaan dan terjaganya hubungan baik dalam perjanjian kerja maka hubungan kerja akan tetap berjalan, itu merupakan salah satu upaya dalam pencegahan pemutusan hubungan kerja.

\section{DAFTAR PUSTAKA}

Adisu, Editus. Jehani, Libertus. 2006. Hak-Hak Pekerja Perempuan. Jakarta : Visi Media.

Djunialdji, FX. 1987. Pemutusan Hubungan Kerja ( Perselisihan Perburuhan

Perorangan ). Jakarta : Bina Aksara. . 2005. Perjanjian kerja

Edisi revisi. Jakarta : Sinar Grafika.

Husni, Lalu. 2003. Hukum Ketenagakerjaan Indonesia Edisi Revisi. Jakarta :
Raja Grafindo Perada.

Jodian, Doni. 2014. Tahukah Anda? Tentang Pekerja Tetap, Kontrak, Freelance,

Outsourcing. Jakarta : Dunia Cerdas.

Kurniawan, Emmanuel. 2013. Tahukah anda?Hak-hak karyawan tetap \& kontrak.

Jakarta Timur : Dunia Cerdas.

Legal, Indonesia Center Publishing. 2006. Peraturan perundang - Undangan

Upah \& Pesangon. Jakarta : Indonesia Legal Center Publishing. Law firm, L\&J. 2012. Pedoman menghitung pesangon dan pensiun. Jakarta :

Rana Pustka.

L, Rukiyah. Syahrizal, Darda. 2013. Undang - Undang Ketenagakerjaan \& Aplikasinya. Jakarta : Dunia Cerdas.

Marzuki, Peter Mahmud. 2005. Penelitian Hukum Edisi Revisi. Jakarta : Kencana. 2008. Pengantar Ilmu Hukum Edisi Revisi. Jakarta : Kencana. Soimin, Soedharyo. 1995. Kitab Undang - Undang Hukum Perdata. Jakarta : Sinar Grafika. Soerjono, Soekanto. 1998. Pengantar Penelitian Hukum. Jakarta : Universitan 
Indonesia Press.

Suwitra, I Made. 2010. Eksistensi Hak

Penguasaan dan Pemilikan Atas Tanah

$d i$

Bali dalam Perspektif Hukum Agraria Nasional. Bandung : Logoz Publishing.

Sumaryati, Eka \& K.,Tini. 2013.Tahukah anda?tentang

PHK\&pesangon. Jakarta

:Dunia Cerdas.

Setia Tunggal, Hadi. 2013. Memahami hukum ketenagakerjaan Indonesia.

Jakarta : Harvarindo.

Sunyoto, Danang. 2014. Juklak PHK.

Yogyakarta : Pustaka Yustisia.

Redaksi, Dewan. 2013. Majalah Ilmu

Hukum Kertha Wicaksana Volume 19

Nomor 3 September 2013 Halaman 248-368. Denpasar : Fakultas Hukum

Universitas Warmadewa Denpasar.

Trijono, Rachmat. 2014. Pengantar

Hukum Ketenagakerjaan. Jakarta : Papas

Sinar Sinanti.

Wijayanti, Asri. 2009. Hukum Ketenagakerjaan Pasca Reformasi. Jakarta : Sinar
Grafika.

\section{Peraturan perundang - undangan}

Kitab Undang - Undang Hukum Perdata (KUHPer).

Undang-Undang Nomor 13 tahun 2003 tentang ketenagakerjaan.

Undang-Undang Nomor 2 tahun 2004 tentang Penyelesaian Perselisihan Hubungan Industrial (PPHI).

Peraturan pemerintah nomor 8 tahun 1981 tentang pengupahan.

Peraturan Menteri Tenaga Kerja dan Transmigrasi Nomor KEP 78/MEN/2001 tentang Penyelesaian Pemutusan Hubungan Kerja dan Penetapan Uang Pesangon, Uang Penghargaan Masa Kerja, dan Ganti Kerugian di Perusahaan.

Peraturan Menteri Tenaga Kerja dan Transmigrasi Nomor KEP 16/MEN/XI/2011 tantang Tata Cara Pembuatan dan Pengesahan Peraturan Perusahaan serta Pembuatan dan Pendaftaran Perjanjian Kerja Bersama. 